\title{
Glucose-induced insulin response and insulin sensitivity is not related to HLA-type but to age in young siblings of Type 1 (insulin-dependent) diabetic patients
}

\author{
F. Lindgren', G. Dahlquist ${ }^{1}$, S.Efendic ${ }^{2}$, E. Möller ${ }^{4}$, B. Persson ${ }^{3}$, B. Thalme ${ }^{5}$ and M. Landin Olsson ${ }^{6}$ \\ ${ }^{1}$ Department of Pediatrics, Karolinska Institute, Sachs' Children's Hospital, ${ }^{2}$ Department of Endocrinology, Karolinska Institute, \\ Karolinska Hospital, ${ }^{3}$ Department of Pediatrics, Karolinska Institute, St. Görans Hospital, Stockholm, \\ Departments of ${ }^{4}$ Clinical Immunology and ${ }^{5}$ Pediatrics, Karolinska Institute, Huddinge Hospital, Huddinge, and \\ ${ }^{6}$ Department of Internal Medicine, Malmö University Hospital, Malmö, Sweden
}

Summary. Glucose-induced insulin response and insulin sensitivity were studied in 32 HLA-identical, 38 haplo-identical and 24 non-identical, islet-cell-antibody-negative, healthy siblings of young Type 1 (insulin-dependent) diabetic patients (age range 10-28 years). No significant differences were obtained between HLA-identical, HLA-haplo-identical siblings and HLA-non-identical siblings in insulin response using an i.v. glucose infusion test even when the insulin sensitivity as estimated by the somatostatin-insulin-glucose infu- sion test was taken into account. A significant inverse correlation to age was found for both insulin response $(r=-0.24, p=0.02)$ and insulin sensitivity $(r=-0.36, p<$ $0.01)$ in the young siblings studied.

Key words: Type 1 (insulin-dependent) diabetes mellitus, etiology, siblings, HLA-types, glucose tolerance test, insulin resistance, age.
Studies of monozygotic twins have shown that if one of the twins has acquired Type 1 (insulin-dependent) diabetes mellitus, then the co-twin runs an approximate $50 \%$ risk of developing Type 1 diabetes [1]. Similarly, HLA-identical siblings of Type 1 diabetic patients run an approximately $30 \%$ risk of developing Type 1 diabetes, whereas the risk for haplo-identical siblings is only $5 \%$. HLA-non-identical siblings run the same risk as the normal population [2].

Many groups have been trying to shed some light on mechanisms responsible for the increased susceptibility to Type 1 diabetes in HLA-identical siblings. An interesting observation was made by Hollander et al. [3], who in a small group of siblings of Type 1 diabetic patients found an exaggerated early insulin response to intravenous arginine and glucose infusion in HLAidentical siblings of Type 1 diabetic patients. Similarly, an exaggerated insulin response to oral glucose was described by Schober et al. [4] in HLA-identical but not in HLA-haplo-identical and HLA-non-identical siblings of Type 1 diabetic patients. It was suggested in these studies that the possibility of a functional disturbance of the B-cell occurs before the appearance of Bcell autoantibodies and it was speculated that the increased B-cell activity could predispose the cells to damage by environmental agents. On the other hand, the appearance of B-cell antibodies in peripheral blood seems to be associated with a decrease of the early insulin response to glucose [5-7]. Although insulin sensitivity was not measured, the findings in the study by Hollander et al. [3] suggested that a slight peripheral insulin resistance might be present in the HLA-identical siblings, contributing to the increased glucose-induced insulin response.

The aim of this study was to analyse the kinetics of insulin release and insulin sensitivity in three subgroups of siblings of Type 1 diabetic-patients: HLAidentical, HLA-haplo-identical and HLA-non-identical. In order to identify a possible modulation of insulin responses by B-cell antibodies, islet-cell antibodies (ICA) have been analysed.

\section{Subjects and methods}

\section{Subjects}

The study was approved by the Ethical Committee of the Karolinska Institute in Stockholm. Informed consent was obtained from all the patients and their parents. Altogether, 159 children with Type 1 diabetes mellitus and 197 healthy siblings from 156 families were typed for HLA-ABC-antigens. Siblings who were HLA-ABC-identical with the proband were further analysed using the mixed lymphocyte culture (MLC) test to ascertain identity. Among the 197 siblings, 38 were HLA-identical, 102 were haplo-identical and 57 were HLAnon-identical. All HLA-identical and groups of age-, sex-, and weight-matched HLA-haplo- and HLA-non-identical siblings, respectively, were invited to further studies of insulin response and insulin sensitivity. Details of the siblings who took part in the study are 
Table 1. Characteristics of siblings subjected to the glucose infusion test (GIT) and the somatostatin-insulin-glucose infusion test (SIGIT)

\begin{tabular}{lclll}
\hline $\begin{array}{l}\text { Group } \\
(n)\end{array}$ & $\begin{array}{l}\text { Age (years) } \\
\text { Mean } \pm \text { SD } \\
\text { (range) }\end{array}$ & $\begin{array}{l}\text { Sex ratio } \\
(\text { male/female })\end{array}$ & $\begin{array}{l}\text { Body mass index } \\
\left(\mathrm{kg} / \mathrm{m}^{2}\right) \\
\text { Mean } \pm \mathrm{SD}\end{array}$ & Comments on SIGIT \\
\hline $\begin{array}{l}\text { HLA- } \\
\text { identical (33) }\end{array}$ & $\begin{array}{c}16.8 \pm 3.9 \\
(11.0-24.3)\end{array}$ & $17 / 16$ & $19.9 \pm 2.4$ & $\begin{array}{l}6 \text { boys, } 5 \text { girls did not perform SIGIT } \\
9 \text { of them younger than 15 years }\end{array}$ \\
$\begin{array}{l}\text { HLA-haplo- } \\
\text { identical (39) }\end{array}$ & $\begin{array}{c}16.8 \pm 4.2 \\
(10.5-27.8)\end{array}$ & $23 / 16$ & $19.8 \pm 2.8$ & 5 boys, 6 girls did not perform SIGIT \\
$\begin{array}{l}\text { HLA-non- } \\
\text { identical (24) }\end{array}$ & $17.1 \pm 4.1$ & $11 / 13$ & $19.6 \pm 2.5$ & 4 of them younger than 15 years \\
\hline
\end{tabular}

summarised in Table 1 . The mean interval between onset of diabetes of the proband and the tests performed on the siblings was 6 years (range 3-18).

\section{Methods}

Glucose infusion test (GIT) and somatostatin-insulin-glucose infusion test (SIGIT) were performed on the morning after an overnight fast. The subjects were instructed to avoid vigorous exercise and alcoholic drinks the day before the test. Indwelling catheters were inserted into both cubital veins. The subjects remained supine during the experiments.

Glucose infusion test (GIT). GIT was performed as described by Cerasi et al. [8]; $500 \mathrm{mg}$ of glucose $/ \mathrm{kg}$-body weight was injected rapidly and followed by a glucose infusion at a rate of $20 \mathrm{mg} \cdot \mathrm{kg}^{-1} \cdot \mathrm{min}^{-1}$ over $60 \mathrm{~min}$. Venous blood samples were drawn at 5-20 min intervals during $120 \mathrm{~min}$. All blood samples were kept on ice until centrifugation. Plasma was frozen at $-20^{\circ} \mathrm{C}$ until analysed. Insulin response was calculated as insulin (incremental) areas.

Somatostatin-insulin-glucose infusion test (SIGIT). SIGIT was performed according to Harano [9] as modified by Wajngot et al. [10]; glucose $\left(6 \mathrm{mg} \cdot \mathrm{kg}^{-1} \cdot \mathrm{min}^{-1}\right)$, insulin $0.4 \mathrm{mU} \cdot \mathrm{kg}^{-1} \cdot \mathrm{min}^{-1}-$ Actrapid, Novo, Copenhagen, Denmark) and somatostatin $(4.5 \mu \mathrm{g} / \mathrm{min}$ - Stilamin, Serono, Rome, Italy) were infused simultaneously. Human albumin ( $20 \%$ Albumin, Kabi Vitrum, Stockholm, Sweden) was added to avoid absorption of insulin to the bottle wall. Subjects less than $50 \mathrm{~kg}$ of weight received reduced amounts of somatostatin $(3.3 \mu \mathrm{g} /$ min). Venous blood samples were drawn every $30 \mathrm{~min}$ for determination of glucose, insulin and C-peptide.

During the test, the C-peptide values were substantially depressed. The mean values \pm SD for all individuals before and at 90 , $120,150 \mathrm{~min}$ were: $0.37 \pm 0.16,0.08 \pm 0.05,0.08 \pm 0.05,0.09 \pm$ $0.08 \mathrm{pmol} / 1$. During the test, circulating insulin levels were stable. The mean values \pm SD for all individuals before and at 90,120 , $150 \mathrm{~min}$ were: $16 \pm 5,24 \pm 4,25 \pm 4,25 \pm 5 \mathrm{mU} / 1$. Insulin and C-peptide levels were similar in the groups studied, e.g. plasma insulin concentrations at $90 \mathrm{~min}$ were $24,24,25 \mathrm{mU} / \mathrm{l}$, respectively.

Since endogenous insulin secretion, was continuously depressed during the test, the blood glucose levels at the end of the test could be used as an estimate of insulin sensitivity. The mean of blood glucose levels at $90,120,150 \mathrm{~min}$ is referred to as SIGIT $(\bar{x})$.

\section{Chemical methods}

Plasma glucose was determined using a commercially available glucose oxidase method - GLOX, Kabi Vitrum, Stockholm, Sweden [11]. Insulin and C-peptide were determined using RIA-methods, commercially available by Novo Company, Copenhagen, Denmark $[12,13]$. HLA-ABC-typing was performed by means of the standard NIH technique and HLA-identity was confirmed using the MLC test [14]. ICA was analysed using a two-colour immunofluorescence technique [15].

\section{Statistical analysis}

As insulin-area and the quotient insulin-area/SIGIT $(\bar{x})$ showed skewed distribution, results are expressed as median, quartiles and ranges. Statistical methods for the evaluation of non-parametric data (Mann-Whitney U-test and Spearman's rank correlation coefficient) were used. For the other variables, Student's t-test was used. A $p$ value less than 0.05 was considered to be statistically significant. A power test was performed for insulin sensitivity showing that with a power of $80 \%$ and a $p$ value of 0.05 , a $25 \%$ difference could be detected using sample sizes of 30 individuals in each group.

\section{Results}

\section{Prevalence of islet cell antibodies (ICA)}

All siblings subjected to the glucose infusion test were analysed for ICA. All were negative except for two siblings - one HLA-identical boy and one HLA-haploidentical girl. When comparing insulin response and insulin sensitivity between the different HLA-groups as described below, these two subjects were excluded.

\section{Insulin response and HLA-type}

The insulin responses and glucose levels in the three different groups are shown in Figure 1 and the exact values for glucose and insulin are given in Table 2. Insulin responses measured as insulin area during the early $0-10 \mathrm{~min}$, late $10-60 \mathrm{~min}$ and total phases did not differ between HLA-identical siblings and HLAhaplo- or HLA-non-identical siblings respectively. The individual values, however, varied markedly. Median, quartiles and ranges are given in Table 3.

\section{Insulin sensitivity and HLA-type}

The insulin sensitivity measured as SIGIT $(\bar{x})$ for the three groups are given in Figure 2. No significant differences were found between the groups. Again, a considerable individual variation is notable.

Insulin response during the glucose infusion test was related to the prevailing insulin sensitivity by calculating the quotient insulin area/SIGIT $(\bar{x})$. This quotient was given as early, late and total phase respectively. Again, no significant differences were found be- 

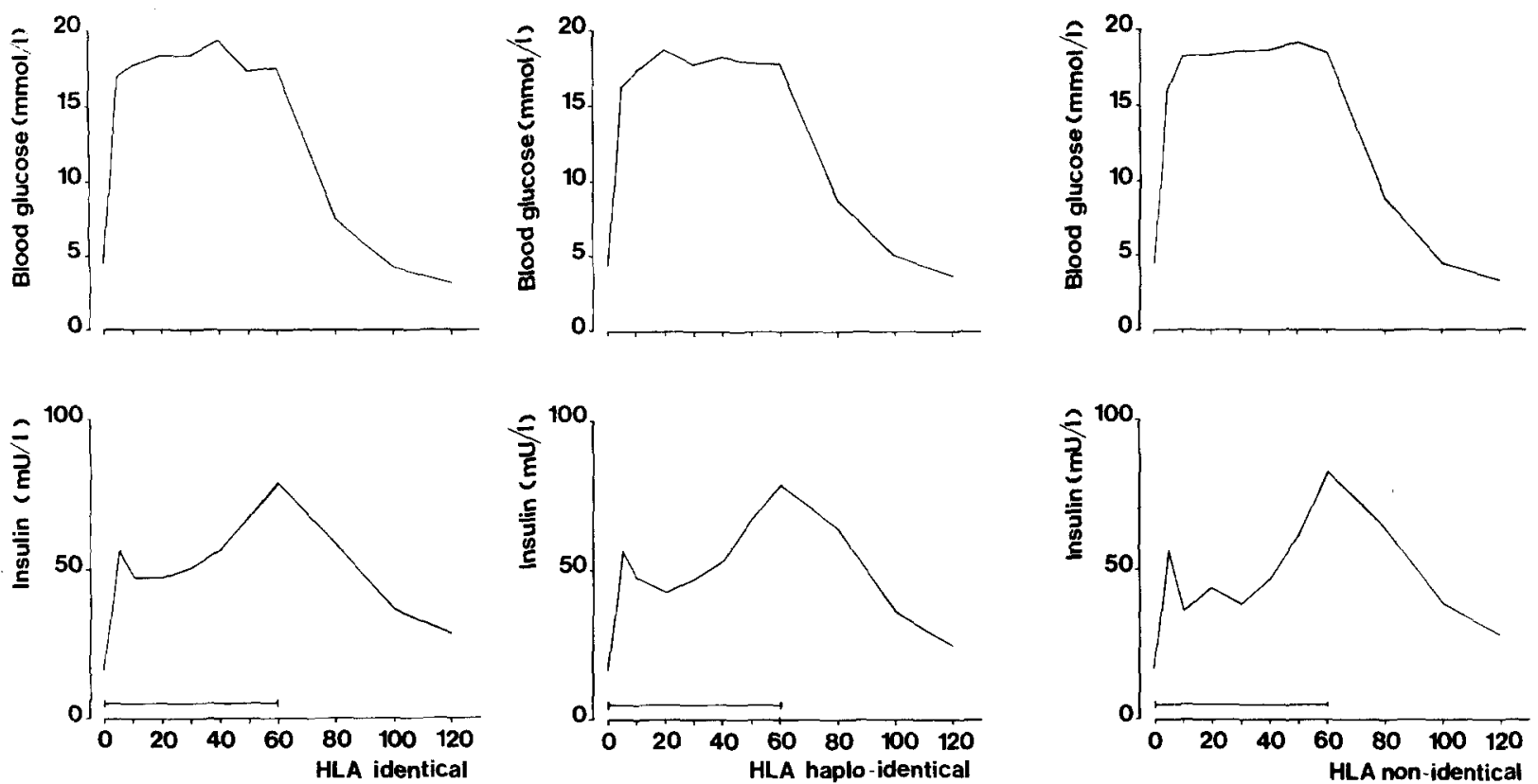

Fig. 1. Glucose and insulin response to the glucose infusion test. Median values in three groups of siblings to Type 1 diabetic patients. Glucose infusion

tween HLA-identical compared to HLA-non-identical siblings and HLA-haplo-identical compared to HLAnon-identical siblings respectively (Table 4).

Analysing all the siblings, insulin sensitivity was inversely correlated to insulin area, i.e. individuals with a high SIGIT $(\bar{x})$ value (low sensitivity) tended to exhibit high insulin responses measured as insulin areas. The correlation between insulin area, early phase and SIGIT $(\bar{x})$ were $r_{\mathrm{s}}=0.31, p=0.01$ and between insulin area total phase and SIGIT $(\bar{x})$ were $r_{\mathrm{s}}=0.35, p<$ 0.01 .

\section{Insulin response, insulin sensitivity, and sex}

There were no significant differences between sexes when comparing the variables insulin area or the quotient insulin area/SIGIT $(\bar{x})$ respectively. However, for SIGIT $(\bar{x})$ a significant difference was found $(p=0.01)$ showing a higher SIGIT $(\bar{x})$ for girls compared to boys when analysing all the siblings.

\section{Insulin response, insulin sensitivity and age}

Insulin area was significantly inversely correlated to age in the total material of siblings: insulin area early phase $r_{\mathrm{s}}=-0.25, p=0.02$; insulin area total phase $r_{\mathrm{s}}=-0.24, p=0.02$. Insulin sensitivity, $\operatorname{SIGIT}(\bar{x})$ was also significantly inversely correlated to age $r_{\mathrm{s}}=$ $-0.36, p<0.01$. A $95 \%$ confidence interval for SIGIT by age in low risk individuals (i.e. HLA-non-identical siblings) was constructed (Fig. 3). The values for the HLA-identical siblings are plotted in the same figure and all values fell within the confidence limits of the low risk individuals.

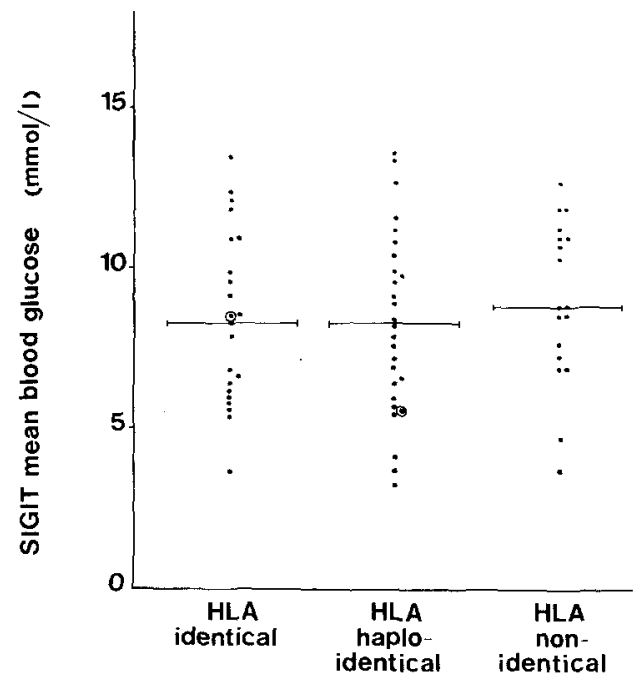

Fig. 2. Insulin sensitivity measured as SIGIT $(\bar{x})$ in the three groups of siblings of Type 1 diabetic patients. ICA-positive siblings are indicated by 0

\section{Diabetes emerged in one sibling}

The HLA-identical sibling who was ICA-positive was a twin brother of a boy who developed Type 1 diabetes at 11 years of age. The healthy co-twin was examined at the age of 16 years when he had a normal fasting blood glucose as well as normal responses to GIT and SIGIT. The early insulin area was 193 and the total insulin area was $1603 \mathrm{mU} \cdot \mathrm{min} / \mathrm{l}$, i.e. close to the lower quartiles of the total material (Table 3). His SIGIT $(\bar{x})$ value was normal as indicated in Figures 2 and 3. At the age of 18 years, the boy had postprandial glucosuria but no clinical symptoms of diabetes. A new GIT was performed which now showed definite pathologi- 
Table 2. Glucose and insulin values during the glucose infusion test in 3 groups of healthy siblings of Type 1 diabetic patients. Glucose values are given as means \pm SD. Because of skewed distribution insulin values are given as medians and quartiles (within brackets)

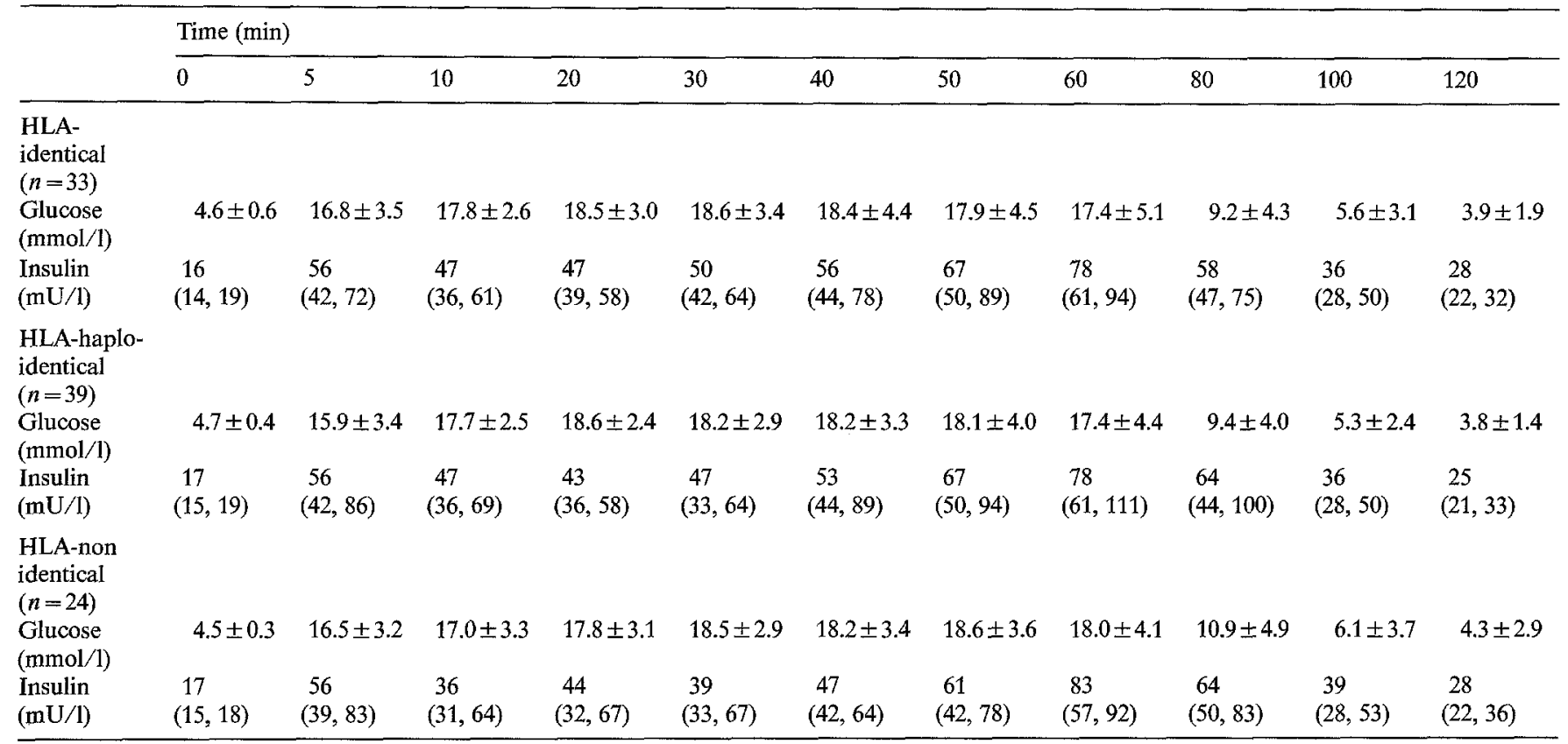

Table 3. Insulin response to the glucose infusion test (GIT) in ICAnegative siblings to Type 1 diabetic patients. Insulin response is calculated as the area under the insulin curve with the base at the 0 min value

\begin{tabular}{|c|c|c|c|}
\hline $\begin{array}{l}\text { Group } \\
(n)\end{array}$ & $\begin{array}{l}\text { Insulin area } \\
\text { early phase } \\
0-10 \mathrm{~min} \\
(\mathrm{mU} \mathrm{min} / \mathrm{l})\end{array}$ & $\begin{array}{l}\text { Insulin area } \\
\text { late phase } \\
10-60 \mathrm{~min} \\
(\mathrm{mU} \mathrm{min} / 1)\end{array}$ & $\begin{array}{l}\text { Insulin area } \\
\text { total phase } \\
0-60 \mathrm{~min} \\
(\mathrm{mU} \mathrm{min} / \mathrm{l})\end{array}$ \\
\hline \multicolumn{4}{|c|}{$\begin{array}{l}\text { HLA- } \\
\text { identical } \\
(n=32)\end{array}$} \\
\hline Median & 259 & 1945 & 2289 \\
\hline Lower q & 191 & 1400 & 1591 \\
\hline Upper q & 368 & 2900 & 3221 \\
\hline Range & $71-1629$ & $600-10695$ & $671-12324$ \\
\hline \multicolumn{4}{|c|}{$\begin{array}{l}\text { HLA-haplo- } \\
\text { identical } \\
(n=38)\end{array}$} \\
\hline Median & 270 & 1875 & 2352 \\
\hline Lower q & 176 & 1390 & 1566 \\
\hline Upper q & 430 & 3135 & 3504 \\
\hline Range & $38-1626$ & $645-6335$ & 683-7961 \\
\hline \multicolumn{4}{|c|}{$\begin{array}{l}\text { HLA-non- } \\
\text { identical } \\
\quad(n=24)\end{array}$} \\
\hline Median & 266 & 1755 & 1966 \\
\hline Lower q & 150 & 1290 & 1502 \\
\hline Upper q & 431 & 2810 & 3211 \\
\hline Range & $65-1018$ & $645-4325$ & $750-5179$ \\
\hline
\end{tabular}

cal glucose and insulin responses and two months later he developed insulin-dependent diabetes.

The other ICA-positive sibling was a haplo-identical girl examined at the age of 12 years. She then had normal GIT and SIGIT tests.
Table 4. The quotient insulin area/SIGIT $(\bar{x})$ in ICA-negative siblings to Type 1 diabetic patients

\begin{tabular}{llll}
\hline $\begin{array}{l}\text { Group } \\
(n)\end{array}$ & Insulin area & Insulin area & Insulin area \\
& $/$ SIGIT $(\bar{x})$ & $/$ SIGIT $(\bar{x})$ & $/$ SIGIT $(\bar{x})$ \\
& early phase & late phase & total phase \\
& $0-10 \mathrm{~min}$ & $10-60 \mathrm{~min}$ & $0-60 \mathrm{~min}$ \\
& $(\mathrm{mU} \mathrm{min} / \mathrm{mmol})$ & $(\mathrm{mU} \mathrm{min} / \mathrm{mmol})$ & $(\mathrm{mU} \mathrm{min} / \mathrm{mmol})$
\end{tabular}

HLA-

identical

$(\mathrm{n}=21)$

median

lower q

upper $\mathrm{q}$

range

$\begin{array}{lcl}31 & 221 & 252 \\ 20 & 181 & 200 \\ 45 & 324 & 379 \\ 12-135 & 93-883 & 105-1019\end{array}$

HLA-haplo-

identical

$(\mathrm{n}=27)$

median

lower $\mathrm{q}$

upper q

range

$\begin{array}{lcc}34 & 229 & 260 \\ 18 & 167 & 193 \\ 55 & 366 & 436 \\ 3-133 & 56-1336 & 59-1469\end{array}$

HLA-nonidentical $(\mathrm{n}=17)$ median

lower q

upper $\mathrm{q}$

range

$\begin{array}{lll}32 & 199 & 221 \\ 22 & 164 & 208 \\ 45 & 332 & 360 \\ 13-76 & 90-440 & 104-483\end{array}$

\section{Discussion}

The present study clearly demonstrates that the insulin response to a standardised glucose infusion test in ICA-negative HLA-identical siblings of young Type 1 
HLA-identical siblings

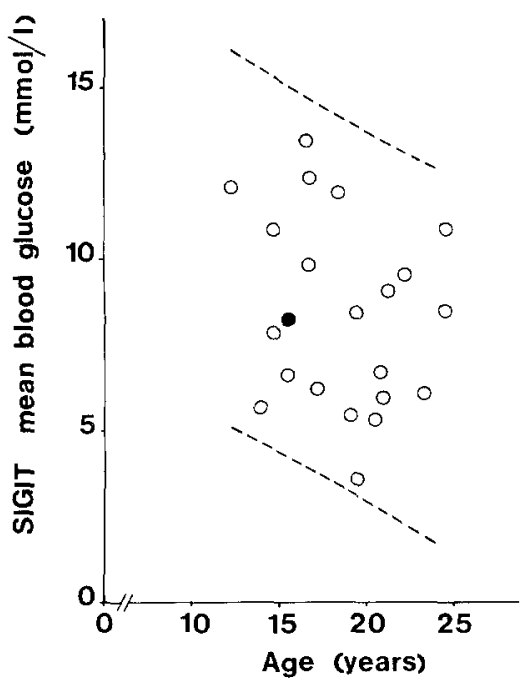

Fig. 3. Insulin sensitivity measured as $\operatorname{SIGIT~}(\bar{x})$ by age. $95 \%$ confidence limits for HLA-non-identical healthy siblings of Type 1 diabetic patients. Regression line: $y=13.9-0.28 x, r=-0.4$. The individual values for HLA-identical siblings are indicated by $O$, all falling within the confidence limits of the low-risk groups. ICApositive, HLA-identical sibling, who later developed Type 1 diabetes mellitus

diabetic patients was not different from that seen in HLA-haplo-identical and HLA-non-identical siblings. Insulin release, however, showed great individual variation. This variation could not be attributed to the presence of B-cell autoantibodies. Thus, we were unable to confirm the observation of a deranged B-cell responsiveness, i.e. an exaggerated acute phase insulin response to intravenous arginine and glucose as reported by Hollander et al. [3]. The reason for the contradictory results is unclear, though methodological differences may play a role. In the present study insulin secretion was stimulated using a glucose bolus followed by glucose infusion during $60 \mathrm{~min}$, while Hollander et al. gave arginine followed by glucose i.v. as bolus doses. Our method may allow a better separation of the maximum, first and second phase insulin responses. It is, however, noteworthy that the same group of investigators [16] using an intravenous glucose tolerance test (IVGTT) recently reported virtually identical insulin responses in HLA-identical siblings of Type 1 diabetic patients compared to that in unrelated control subjects. In our study, subjects belonging to three HLA-subgroups of siblings of Type 1 diabetic patients exhibited a wide range of insulin responses ranging from low to very high. Thus, one reason for the conflicting results between our and earlier studies may be that HLA-identical siblings of Type 1 diabetic patients are a heterogenous group of individuals, where some subjects could exhibit an early derangement in B-cell responsiveness. Only follow-up studies of large groups of siblings may give the answer.

In order to better evaluate the response of insulin, insulin sensitivity was also tested. This is of particular interest since, as discussed by Wajngot et al. [10], low insulin response in relation to prevailing insulin sensitivity may be an early event in the development of diabetes. It is also of importance since insulin resistance has been shown to vary during the early natural course of Type 1 diabetes [17]. In our study, it was shown that there is a significant correlation between insulin response and insulin sensitivity, but there was no difference between the three groups of HLA-typed siblings. Thus the insulin responses in the three groups of siblings were not different although insulin sensitivity was taken into account.

In contrast to our findings, Raghu et al. [16] have recently reported decreased insulin sensitivity in HLAidentical siblings of Type 1 diabetic patients compared to matched unrelated control subjects. These authors determined the insulin sensitivity index on the basis of an IVGTT using the minimal model of insulin kinetics. There is a good correlation between the sensitivity index as derived from an IVGTT and that derived from an euglycaemic clamp [18], suggesting that the opposite results reached in their and our studies are probably not of a methodological character. The relatively large number of siblings in the HLA subgroups in the present study would be enough to detect a difference of a least $25 \%$ of the SIGIT $(\bar{x})$ values with a power of $80 \%$ and a probability of $5 \%$. Furthermore, in our study HLA-identity was based not only on HLA-ABCtyping, but also confirmed by the MLC-test. This could be important, as recent studies have shown that the strongest association between HLA antigens and susceptibility of Type 1 diabetes may be present in the DQ region [19]. Again, a possible explanation for the diverging results may be that HLA-identical siblings represent a very heterogenous group, insulin resistance being a characteristic feature of some of these individuals.

An important finding of the present study was the demonstration of an age dependency of both insulin response and insulin sensitivity in young, healthy individuals. However, the correlations are low, indicating low fractions of explained variances. Our observation is in agreement with that of Amiel et al. [20], who studied both non-diabetic and diabetic individuals. Thus, these authors found a lower insulin sensitivity in adolescents compared to both prepubertal and adult subjects, irrespective of the fact if they had diabetes or not. Our findings of an age dependency of both insulin response and insulin sensitivity underlines the importance of taking age into account when interpreting such data.

Acknowledgements. This study was supported by grants from the Nordic Insulin Research Funds, the Karolinska Institute, and The Swedish Diabetic Foundation. 


\section{References}

1. Barnett AH, Eff C, Leslie RDG, Pyke DA (1981) Diabetes in identical twins. A study of 200 pairs. Diabetologia 20: 87-93

2. Gorsuch AN, Spencer KM, Lister J, Wolf E, Bottazzo GF, Cudworth AG (1982) Can future type 1 diabetes be predicted? A study in families of affected children. Diabetes 31: 862-866

3. Hollander PH, Asplin CM, Kniaz D, Hansen JA, Palmer JP (1982) Beta-cell dysfunction in non-diabetic HLA-identical siblings of insulin-dependent diabetics. Diabetes 31: 149-153

4. Schober E, Schernthaner G, Frisch H, Bieber J, Mayr W (1983) Beta-cell function in siblings of diabetic children and HLA-type. Arch Dis Child 58: 923-925

5. Srikanta S, Ganda OP, Gleason RE, Jackson RA, Soeldner JS, Eisenbarth GS (1984) Pre-type 1 diabetes. Linear loss of beta-cell response to intravenous glucose. Diabetes 33: 717-720

6. Srikanta S, Ganda OP, Jackson RA, Brink SJ, Fleischnick E, Yunis E, Alper C, Soeldner JS, Eisenbarth GS (1984) Pre-type 1 (insulin-dependent) diabetes: common endocrinological course despite immunological and immunogenetic heterogeneity. Diabetologia 27: 146-148

7. Ginsberg-Fellner F, Witt ME, Franklin BH, Yagihashi S, Toguchi Y, Dobersen MJ, Rubinstein P, Notkins AL (1985) Triad of markers for identifying children at high risk of developing insulin-dependent diabetes mellitus. JAMA 254: 1469-1472

8. Cerasi E, Luft R (1967) The plasma insulin response to glucose infusion in healthy subjects and in diabetes mellitus. Acta Endocrinol (Copenhagen) 55: 278-304

9. Harano Y, Ohgaku S, Hidaka H, Haneda K, Kikkawa R, Shigeta $Y$, Abe $H$ (1977) Glucose, insulin and somatostatin infusion for the determination of insulin sensitivity. J Clin Endocrinol Metab 45: 1124 1127

10. Wajngot A, Luft R, Efendic' S (1983) Oral glucose tolerance test and insulin in low insulin responders. Acta Endocrinol (Copenhagen) $104: 77-84$

11. Hjelm M (1966) Enzymatic determination of hexoses in blood and urine. Scand J Clin Lab Invest 18 [Suppl] 192: 85-98
12. Heding LG (1972) Determination of total serum insulin (IRI) in insulin-treated diabetic patients. Diabetologia 8: 260-266

13. Heding LG (1975) Radioimmunological determination of human c-peptide in serum. Diabetologia 11: $541-548$

14. Bain B, Magdalene RV, Lowenstein L (1964) The development of large immature mononuclear cells in mixed leucocyte cultures. Blood 23: 108-116

15. Madsen OD, Landin Olsson M, Bille G, Sundkvist G, Lermark $\AA$, Dahlquist G, Ludvigsson J (1986) A two-colour immunofluorescence test with a monoclonal human pro-insulin antibody improves the assay for islet cell antibodies. Diabetologia 29: $115-118$

16. Raghu P, Johnston C, Beard JC, Bergman R, McCulloch DK, Palmer JP (1985) Reduced insulin sensitivity in non-diabetic, HLA-identical siblings of insulin-dependent diabetic subjects. Diabetes 34: 991-994

17. Yki-Järvinen H, Koivisto VA (1986) Natural course of insulin resistance in type 1 diabetes. N Engl J Med 315: 224-230

18. Beard JC, Bergman RN, Ward WK, Porte D (1986) The insulin sensitivity index in non-diabetic man. Diabetes 35: 362-369

19. Lernmark $\AA$ (1985) Molecular biology of type 1 (insulin-dependent) diabetes mellitus. Diabetologia 28: 195-203

20. Amiel SA, Sherwin RS, Simonson DC, Lauritano AA, Tamborlane WV (1986) Impaired insulin action in puberty. A contributing factor to poor glycemic control in adolescents with diabetes. New Engl J Med 315: 215-219

Received: 7 January 1987

and in revised form: 21 July 1987

Dr. Fredrik Lindgren

Department of Pediatrics

Sachs' Children's Hospital

Sachsgatan 1

S-11669 Stockholm

Sweden 